\title{
CIVILIZAÇÃO TROPICAL EM PERIGO: CINEMA, ELITE E CLASSES MÉDIAS NA BELLE ÉPOQUE CARIOCA
}

Pedro Vinicius Asterito Lapera

\section{Introdução}

Em uma manhã de fevereiro de 1916, quase às vésperas do Carnaval, os leitores dos jornais cariocas foram surpreendidos por um fato insólito: um tiroteio em um dos cinematógrafos do Rio de Janeiro. Atônitos, os cronistas dos diversos periódicos relataram versões e detalhes sobre o curioso fato que se passara na véspera no Cinema Odeon, localizado na Avenida Rio Branco, bem no coração da nova cidade planejada pelo prefeito Pereira Passos.

O fait divers ${ }^{1}$ do Odeon ocupou espaço nos jornais ao longo dos meses seguintes, que acompanharam com avidez o desenlace da acolhida bizarra em uma sessão de cinema. Apresentaram publicamente os protagonistas do conflito e os lances em torno do julgamento do crime, destacando detalhes em suas narrativas que corroboravam suas versões e tomando partido por um dos lados.

O objetivo deste artigo é mostrar como, apesar de ser um fato que não tenha tido impacto nos rumos da conturbada Primeira República, as narrativas veiculadas entre os meses de fevereiro e junho de 1916 pelos periódicos cariocas podem ser consideradas indícios de tensões sociais projetadas no ato de ir ao cinema. Ainda, defendemos que alguns detalhes dessas narrativas podem nos ajudar a compreender certos horizontes de expectativas sobre o consumo cinematográfico enquadrados pela visão dos setores médios da população.

Em uma aproximação entre história cultural e etnografia, alguns historiadores já destacaram a relevância ou a pertinência de documentos ou conjuntos documentais produzidos por sujeitos à margem das estruturas de poder de uma determinada época para compreender os padrões de comportamento e as estruturas sociais do passado. No seu consagrado estudo sobre as lettres de pardon, intitulado Fiction in the archives: pardon tales and their tellers in the sixteenth-centure France (1990), Natalie Zemon Davis analisou 
como sujeitos comuns que cometeram crimes graves se valiam de determinadas estruturas narrativas para tentar obter o perdão do rei e, assim, evitar a execução da pena de morte. Já em O Queijo e os vermes: o cotidiano e as ideias de um moleiro perseguido pela Inquisição (1987), Carlo Ginzburg verificou através dos processos da Inquisição como os livros apreendidos na casa de um moleiro chamado Menocchio e os interrogatórios a que ele foi submetido poderiam servir de acesso à mentalidade dos camponeses trentinos do século XIV.

Em outro trabalho, Ginzburg dissertou sobre seu método de investigação, chamado de paradigma indiciário. No ensaio "Sinais: raízes de um paradigma indiciário" (2007), o autor considerou que, a partir dos vestígios deixados pelas fontes que sobrevivem ao desgaste do tempo, é possível acessar algumas estruturas sociais do passado e lançar questões a respeito das ações de indivíduos e grupos. De acordo com Ginzburg, "se a realidade é opaca, existem zonas privilegiadas - sinais, indícios - que permitem decifrá-la" (2007:177).

Consideramos as narrativas veiculadas pelos periódicos depositados na Biblioteca Nacional sobre este fait divers vestígios da formação de uma cultura ligada aos setores médios que vinha então se estabelecendo. Ainda, suspeitamos que o consumo cinematográfico mostrou-se fundamental na afirmação de alguns valores ligados a essa cultura de classe média. Para fins deste artigo, consideramos cultura como "as estruturas de significado através das quais os homens dão forma à sua experiência" (Geertz 1989:207), inserindo-nos no mesmo horizonte intelectual dos historiadores já mencionados na sua relação com a escrita das práticas culturais em uma perspectiva histórico-antropológica.

É preciso fazer uma breve exposição sobre as fontes utilizadas neste trabalho. Em um primeiro momento, foram coletadas, tanto no acervo físico depositado na instituição quanto no acervo digitalizado na Hemeroteca Digital da Biblioteca Nacional, 98 fontes - entre artigos, charges, editoriais, cartas de leitores enviadas à redação dos jornais - em 10 periódicos que circulavam pela cidade do Rio de Janeiro, uma amostra da razoável repercussão que o fato teve à época. Em um tratamento posterior, selecionamos dentre aqueles, 39 fontes como corpus a ser analisado.

Salientamos também a heterogeneidade das fontes utilizadas. Alguns dos periódicos eram diários e de grande circulação, tais como Jornal do Brasil e Correio da Manhã, outros tinham periodicidade mais irregular como A Época e A Prensa; outros tinham uma proposta claramente satírica direcionada à política e aos costumes, tal como O Malho. Esses periódicos têm em comum o fato de terem surgido no final do Império e durante a Primeira 
República como plataformas de divulgação de ideias liberais e republicanas, sendo necessário considerar o papel central que desempenhavam na difusão dessas ideias na vida pública do período (Barbosa 2007:21-48).

A discussão proposta transitará em torno da apresentação pública do conflito e de seus personagens, a relação com o ato de ir ao cinema e as diferentes abordagens propagadas pela imprensa carioca. A questão principal que irá nortear este artigo é: de que modo estes sujeitos pertencentes à classe média e à elite projetaram algumas tensões sociais no consumo cinematográfico por ocasião do fait divers a ser analisado? Como questão secundária, pretendemos investigar quais concepções a respeito do termo "civilização" foram usadas nas narrativas veiculadas pelos periódicos da época e como atuaram nas interpretações do conflito que resultou no tiroteio.

Enquadramos nosso esforço dentro da discussão de John e Jean Comaroff a respeito de como a etnografia deve lidar com a imaginação histórica. Segundo os autores, "essas 'histórias ocultas', parciais, precisam ser situadas em mundos mais complexos de poder e significado que deram vida a elas" (1992:17). A concepção de história dos autores "envolve a sedimentação de micropráticas e macroprocessos" (1992:38) e se revela crucial para a nossa discussão, visto que precisamos considerar a relação entre os fragmentos deixados pelo tempo a respeito deste fato e sua inserção em processos de estruturação e mudança social.

Nossa hipótese principal é a de que o fato analisado envolve dois polos em termos de classe que estruturam a dinâmica do seu desenlace, sendo uma metonímia de uma série de conflitos entre visões de mundo e de agir dessas classes. Todavia, esses polos não podem ser lidos de modo absoluto, uma vez que as posições variam no conflito e são perpassadas por categorias ligadas à raça e a gênero, embora em menor escala.

Como hipótese secundária, acreditamos que os cronistas dos periódicos analisados colocaram-se como guardiães da "ordem" e da "civilização", uma postura que se relaciona à posição de classe destes, em sua maioria, homens pertencentes aos estratos médios da população - funcionários públicos, literatos, comerciantes. Além disso, podem ser considerados também observadores participantes dos fatos retratados - no sentido de que estão inseridos em redes de interpretação, de comunicação e de poder do momento avaliado - e, portanto, suas narrativas são centrais para nosso argumento ${ }^{2}$.

O presente texto se divide em duas partes. Na primeira, analisamos as motivações do conflito e como estas foram percebidas não apenas pelos envolvidos, mas também pela imprensa que deu ressonância ao fato, a partir de um debate sobre "civilização" e ida a cinematógrafos. Por sua vez, na segunda parte, escolhemos como foco o papel dos militares na conformação 
de uma cultura de classe média no Rio de Janeiro das primeiras décadas do século XX. Aliando-se a outros setores médios da população, atuaram também na propagação de uma "ideologia da ordem" e nas restrições à presença das mulheres num espaço urbano altamente hierarquizado.

\section{O chapéu da discórdia: a ida ao cinema e tensões sociais na Primeira República}

Na noite de 10.2.1916, durante uma sessão de cinema no Odeon, quatro personagens se envolveram em uma discussão acalorada que se transformou subitamente em confronto físico. O coronel do Exército Antônio Mendes de Moraes e o coronel da Guarda Nacional João Cavalcanti do Rego sentiram-se incomodados pela recusa do espectador sentado à frente em tirar o chapéu durante a projeção do filme Maciste. Por sua vez, João Vaz de Carvalhaes e Line Dunchen ${ }^{3}$, ofendidos pelo "tratamento indigno" dado pelos primeiros de cochichar e apontar com deboche em sua direção, investiram contra estes e iniciaram a discussão que culminou com um tiro.

Em seguida, as luzes do cinematógrafo foram acesas, a orquestra, interrompida, pessoas tentavam invadir o cinema para linchar o atirador, outras corriam desesperadas fugindo da confusão, até que, finalmente, a polícia interveio e conduziu os coronéis à delegacia. Embora com elementos insólitos, o fato parece relativamente simples em termos narrativos, com estrutura clara e protagonistas e antagonistas aparentemente definidos.

No entanto, não foi o que verificamos ao analisar as fontes. A apresentação dos fatos narrados foi marcada por uma disputa de versões que envolveu os cronistas dos periódicos cariocas em todos os momentos da cobertura jornalística. O jornal A Noite resumiu o conflito da seguinte forma:

O Sr. Carvalhaes não tirara o chapéo. Falava em francez com sua companheira.

- Esse sujeito pensa que isto aqui é terra de botocudos. Não vê que está a tirar a vista com o seu chapéo.

- É a mim que o senhor se dirige? Pensa que está falando com um negro?

O dialogo continuou num crescendo de animos. Os dous coroneis apontaram o chapéo do joven, que julgavam a principio ser estrangeiro ${ }^{4}$.

A recusa de Carvalhaes em tirar o chapéu durante a projeção cinematográfica e as ofensas racistas proferidas por ambas as partes durante a discussão foram apresentadas como o leit motif do trágico desfecho em todas as narrativas analisadas. Entretanto, as leituras feitas em torno desses aspectos do conflito diferiram bastante entre as fontes. A crônica publicada 
pelo periódico A Época, por exemplo, destaca os mesmos elementos a partir do ponto de vista de defesa dos militares:

O Brazil é um paiz victima delle proprio. A sociedade brasileira soffre sempre as amarguras sociaes que lhe infligem a ingenuidade e a facilidade com que sempre recebe, de alma e braços abertos, [...], todo o máo elemento que o estrangeiro civilizado joga na lata do lixo.

[...] O sr. Carvalhaes, millionario, bohemio, elegante, conhecedor, talvez, da nossa apathica covardia, julgou, porventura, poder promover um escandalo numa sala em que se achara a sociedade carioca selectamente reunida, e desrespeitar, sem temores, o primeiro cavalheiro que lhe aparecesse, fosse este quem fosse. Entrar numa sala de espectaculos e tirar o chapéo ao começar dos mesmos, parece-nos que é acto de cortesia. O sr. Carvalhaes, porém, achou que isso não era assim e, não obstante ser sollicitado, continuo com o seu chapéo á cabeça, importunando a vista da senhora que estava por detraz ${ }^{5}$ [grifo nosso].

Tal perspectiva foi validada por outras publicações como O Paiz ${ }^{6}$, importante plataforma política das ideias liberais à época. Em oposição a isso, $A$ Notícia publicou um artigo tendo como ponto de vista a defesa do visconde alvo do tiro e de sua companheira:

Deste lado, alinharam-se publicações como Careta ${ }^{7}$, O Malho ${ }^{8}$ e Jornal do Brasil ${ }^{9}$. A partir dessas narrativas, é possível tecer algumas considerações sobre o motivo do conflito. O fato de existir uma disputa em torno da possibilidade de usar chapéu durante a ida ao cinema configura um indício de que o hábito de tirar o chapéu ainda não era uma convenção consolidada. E as leituras discrepantes revelam duas concepções sobre o ato de ir ao cinema: a primeira, exemplificada por A Época, priorizava o aspecto coletivo da diversão e pregava o respeito ao espaço comum partilhado pelos espectadores; a segunda, encampada por A Notícia, colocava destaque na dimensão individual da espectatorialidade e da busca do prazer através do consumo.

Partindo do aspecto ritual do consumo, é possível perceber que este também é revestido de uma aura agonística, mais precisamente que o consumo "é a própria arena em que a cultura é objeto de lutas que lhe conferem forma" (Douglas \& Isherwood 2004:103). No caso da ida ao cinema, trata-se de um ritual caro à expansão da modernidade. Assim, as condutas que a perpassavam encontravam-se em formação, sobretudo em um momento em que a presença das salas de cinema na paisagem urbana era um fenômeno historicamente recente ${ }^{10}$. Fazia-se necessário um processo civilizador específico à espectatorialidade cinematográfica, voltado à disciplina e à pedagogia do público enquanto indivíduos e também como parte de um grupo maior, que não ocorreu sem tensões e que inclusive operou com seleções, elimina- 
ções de hábitos e incorporação de outros novos a partir dos rearranjos nas relações de poder, na mesma linha do que já foi analisado por Elias (1993, 1994) em relação ao mundo moderno.

Quanto às ofensas racistas deflagradoras do confronto físico entre as partes, podemos situá-las dentro de um senso comum (Berger \& Luckmann 1996) que privilegiava um ideal de branqueamento que vinha sendo defendido durante as décadas anteriores nos debates acadêmicos (Schwarcz 2005) e também incorporado às ações e às políticas de Estado (Vianna 1999; Cunha 2002).

Não encontramos uma fonte dentre as analisadas que contestasse as ofensas proferidas, nem mesmo em um comentário inserido em uma narrativa mais ampla. Essa ausência pode ser interpretada como um indício da legitimidade desse ideal de branqueamento no senso comum, o que levou ao fato de este diálogo ter sido replicado com tanta naturalidade pela imprensa da época.

Diante disso, podemos considerar que os usos do racismo científico, expresso por estereótipos, no diálogo que antecedeu o conflito e veiculado nas narrativas da imprensa não são elementos incidentais nem conjunturais, mas estruturais do que se entendia por "civilização" na cultura de classe média em formação no Rio de Janeiro das primeiras décadas do século XX, da qual os cronistas dos periódicos cariocas eram porta-vozes.

Essa interpretação encontra-se em consonância com uma historiografia brasileira que aborda as camadas populares no período em questão, suas lutas e sua relação com os poderes constituídos, com os setores médios e com a elite, e que, ao considerar em suas análises questões raciais e/ou étnicas, aponta a dimensão estrutural do ideal de branqueamento nas relações entre sujeitos e grupos (Nascimento 2001; Schettini 2006; Sevcenko 1984; Chalhoub 1996, 2012; Morel 2009).

Além disso, as ofensas racistas tocam em outro ponto: a autoimagem que os espectadores de cinema faziam de si nas primeiras décadas do século XX. Como duas das funções do consumo são a de demarcar fronteiras sociais e a de classificar eventos e pessoas (Douglas \& Isherwood 2004:39), o comentário do coronel Moraes a respeito de Carvalhaes ("esse sujeito pensa que isto aqui é terra de botocudos. Não vê que está a tirar a vista com o seu chapéo") é sintomático de quem na sua visão tem o direito de frequentar o cinema. O adjetivo "botocudos" aqui opera como metonímia para não civilizados, indignos de estarem no espaço coletivo do cinema, alijados de um processo civilizador caro à modernidade. E a réplica de Carvalhaes ("É a mim que o senhor se dirige? Pensa que está falando com um negro?") reitera essa autoimagem, na medida em que escolhe outro grupo como alvo do estigma 
(Goffman 1988), igualmente ausente do referido processo civilizador na visão dos personagens.

Deste modo, identificamos a exclusão de determinados grupos do espaço de sociabilidade e a negação à representação caminhando pari passu na afirmação de um projeto de civilização pautada pelo branqueamento. E, completando o ciclo, define-se assim quem ocupa o polo oposto à civilização, ou seja, a barbárie: indivíduos não brancos.

Ironicamente, o grupo desprezado na fala de Carvalhaes fazia-se presente na tela do Odeon justamente na hora do confronto. Podemos extrair de uma crítica ao filme Maciste, publicada na Gazeta de Notícias, algumas informações relevantes para o nosso argumento:

\section{Maciste? Maxixe? Massada?}

Não se sabe bem.

A annunciada obra prima de "Itala" não passa, no final de contas, de uma exposição de musculos de um lutador de circo. O negro gigante tinha sido apreciado em "cabiria", de D'Annunzio e a fabrica de films resolveu aproveitar a sua única qualidade, que era o "muque", para cavar outra fita. Mas o desastre não poderia ser mais completo. "Maciste", ou melhor "massada", não tem enredo, deixa muito a desejar como movimentação e os episodios desenrolam-se sempre em torno do negro fatal, que agarra os bandidos como bonifrates, sacode-os e, no fim, vence-os, como nos dramalhões, para punir o vício e premiar a virtude.

[...] Além do que, ha sempre o terror de que, emquanto na tela "Maciste" faz massadas, muitas massadas, na sala, dous coroneis irritados dem tiros, aproveitando a escuridão, nos espectadores que se não sujeitam ás suas insolencias. Os frequentadores não se acham garantidos na sala do Odeon e não vale a pena arriscar a vida para ver "films" sem importância"11 [grifos nossos].

Na própria crítica ao filme exibido na sessão consta o estereótipo do homem negro como primitivo, dotado de um senso de justiça básico, incapaz intelectualmente e que só consegue se afirmar pela força bruta. Esta imagem certamente reforçava o alijamento simbólico de sujeitos não brancos do processo civilizador específico representado pelo consumo cinematográfico. Isto não significa afirmar que a população negra do Rio de Janeiro era fisicamente impedida de estar em uma sala de cinema, mas apenas reconhecer a eficácia de uma barreira simbólica imposta a ela, assim como a exclusão desse grupo da autoimagem feita pelos espectadores de cinema no Rio de Janeiro do começo do século XX.

Elias considerou o processo civilizador como "uma mudança na conduta e sentimentos humanos rumo a uma direção muito específica" (1993:193). Apropriando-nos de sua discussão, podemos afirmar que, na modernidade, 
o consumo cinematográfico foi deflagrador de alguns rituais, demandando condutas específicas à sua fruição.

Com isso, entramos na questão do autocontrole, aspecto fundamental do processo civilizador analisado por Elias. Considerando a tensão entre indivíduos e estrutura social como constituinte da modernidade (Elias 1994:16-19) e que a própria categoria indivíduo ascendeu com ela (1994:134), o autor observou que, ao longo das mudanças históricas trazidas pela modernidade, houve o reforço dos mecanismos de autocontrole ou, melhor dizendo, de "formas particulares de autorregulação da pessoa em relação a outras pessoas e coisas" (1994:36). Em princípio relacionado ao corpo, este autocontrole passou a perpassar também as funções psíquicas nas relações entre indivíduos e grupos sociais.

A charge publicada pelo jornal $A$ Noite $^{12}$ traz a mesma referência inicial do processo civilizador descrito por Elias: a Idade Média e seus cavaleiros.

\section{SUPER-CIVILISAÇÃ̃O}

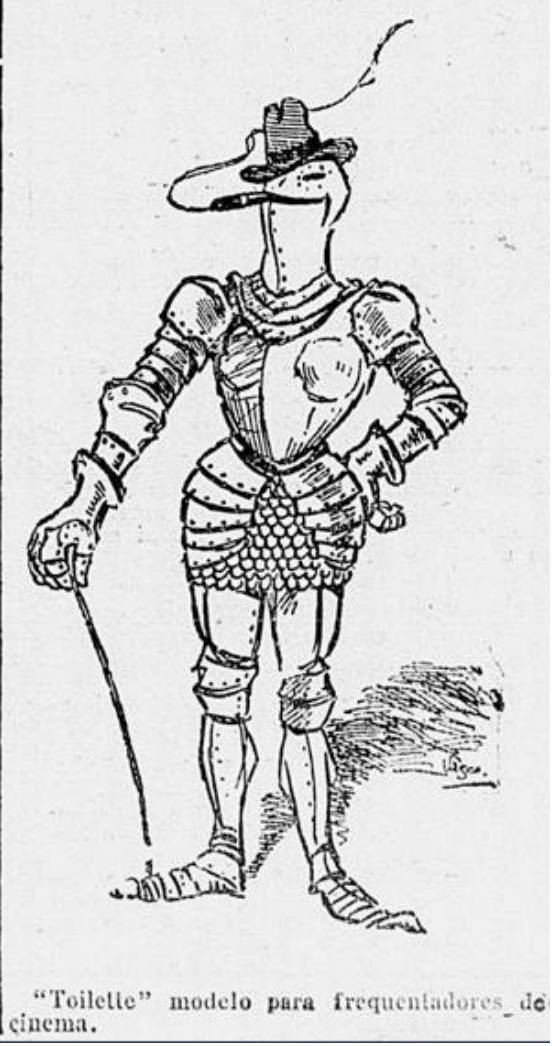

Fonte: Hemeroteca Digital da Biblioteca Nacional 
Apresentada na primeira página do jornal com o título "super civilização", a charge ironiza o episódio e, por conseguinte, o ato de ir ao cinema, tendo como referente a sociedade carioca da época. A armadura medieval ilustra a crítica aos indivíduos envolvidos no confronto, uma vez que foram tidos como incapazes de dominar seus impulsos de agressividade. O autocontrole era um elemento caro à cultura burguesa desde o século XVIII, que foi aos poucos se consolidando ao longo do século XIX e divulgado como padrão de comportamento adequado à classe média em formação (Gay 2002). E a cara do cavaleiro substituída por um sapo amplia essa crítica, pois opera um evidente rebaixamento de suas condutas, animalizando-o.

É interessante notar que as charges eram veiculadas na primeira página dos periódicos diários, via de regra, de modo a ser um elemento visual para chamar a atenção dos leitores sobre os fatos de ordem política, econômica ou de costumes considerados relevantes pela sua linha editorial. Disto podemos inferir que a charge descrita é um indício do interesse do público carioca - devidamente filtrado pela editoria da publicação - sobre o incidente ocorrido no cinematógrafo.

Já a crônica intitulada "O Crime do Cinema", publicada no jornal A Notícia ${ }^{13}$, descreveu a cena no Odeon como um pretenso "choque de civilizações".

[...] Não houve nesse facto, que toda a nossa civilização condemna, um drama propriamente dito, com as almas açuladas por uma paixão violenta, mas a explosão [...] de sentimentos muito exaltados de patriotismo e educação. É o depoimento de um dos protagonistas da scena cannibalesca quem [...] affirma ter dito, deante da teimosia da victima em conservar na cabeça o [...] chapéo, que aquella grosseria só podia partir de um estrangeiro e não de um brazileiro. Temos assim que o "pivot" do drama imprevisto foi uma superexcitação, uma hyperesthesia brusca do sentimento de patriotismo e de civilização cis-atlantica, quer dizer puramente aborigene, de dois cavalheiros [...] que se revoltaram cegamente contra a grosseria inominavel de um "estrangeiro". Esses dois illustres e requintados cavalheiros, na sala tenebrosa do cinema, que é um invento da civilização estrangeira e muito apreciado pela civilização das nossas avenidas e sertões circumjascentes, não viram mais deante de si senão a insolencia de um chapéo representando a insolencia de uma civilização estrangeira, naturalmente a civilização franceza, porque o cidadão que assim se mostrava despresador e acintoso que só se exprimia em francez. E não houve mais o recurso de opor civilização contra civilização, requintando na superioridade da nossa sobre a desse "estrangeiro". O que mais magoou talvez nessa affronta foi a cathegoria de "estrangeira". Nós podemos perdoar-nos, e muitas vezes nos perdoamos, uns aos outros [...] os que são praticados por estrangeiros são mais revoltantes, por 
isso que são já a affronta e o insulto, e o estrangeiro é o bárbaro, o adversário que nos vem offender na nossa casa. Dahí a revolta do nosso patriotismo que faz questão de um chapéo na sala de um cinema, não acceitando a escusa de um descuido, de uma distracção do seu portador e investindo para elle com uma violencia em que deve vibrar todo o instincto da raça e da nacionalidade [grifos nossos].

Tendo como referente a barbárie ("scena canibalesca"), a crônica faz um relato irônico centrado nos protagonistas da patética cena. Neste ponto, é possível propor aqui, para fins de análise, substituir na narrativa do cronista o termo "civilizações" por "classes". Transformado pelo cronista em personagem, o chapéu se situa no meio da disputa entre membros de uma elite com uma visão de mundo exclusivista e individualista e de sujeitos de uma classe média bastante ressentida deste comportamento.

Ainda, podemos expandir este argumento para ressaltar que o conflito se refere ao uso do espaço semipúblico representado pelo cinematógrafo ${ }^{14}$. Tal visão a respeito de um uso tido como inadequado foi colocada em disputa pelos sujeitos, de modo que um senso coletivo na apreciação dos filmes e do espaço do cinema foi superposto por uma dimensão privatista/individualista, sendo este espaço semipúblico tratado como uma mera expansão do espaço privado.

O preço médio da entrada de cinematógrafo no Rio de Janeiro, à época, representava uma barreira à presença das classes mais baixas ${ }^{15}$. contrariamente ao que se deu, por exemplo, nos EUA, onde a expansão do mercado cinematográfico foi ancorada no consumo das classes populares, inclusive de imigrantes (Musser 1994; Hansen 1991). Em sua análise sobre o lazer das classes populares no Rio de Janeiro, Chalhoub (2012) desenvolveu o argumento de que a renda das mesmas era usada prioritariamente em itens de subsistência, sobrando muito pouco para lazer e poupança, o que as levava a optar por locais de fácil acesso, como o bar.

No entanto, o preço do ingresso no cinema não era proibitivo à classe média em ascensão no Rio de Janeiro desde meados do século XIX (Needell 1993), o que tornava a sala de cinema um espaço de sociabilidade comum à elite e à classe média. O censo de 1906 apontou que cerca de $1 / 4$ da população carioca economicamente ativa ocupava postos relacionados à classe média, tais como funcionários públicos, empregados do comércio e profissionais liberais ${ }^{16}$. Embora não representassem a maioria da população, certamente eram uma fonte relevante para a expansão do público cinematográfico na então capital federal.

Na crônica, a punição à insolência do visconde "estrangeiro", que ousara atentar contra o sentimento de "nativismo tropical", foi o tiro. Em 
outros relatos, apareceram também as punições a que foram submetidos o autor do disparo e seu companheiro, sendo a tentativa de linchamento por parte da população que invadiu o cinema após o fato a principal delas.

Neste ponto, o público alijado do consumo cinematográfico (classes populares) assume o protagonismo da cena na punição dramática aos vilões. O tom de muitas narrativas sobre o fait divers podem ser percebidas como a melodramatização da experiência social (Singer 2001), sobretudo se considerarmos o papel dos indivíduos em relação às classes sociais que representam: metonimicamente, enquanto a elite tenta reafirmar sua posição de privilégio, a classe média, por sua vez, faz apelo a uma convenção pretensamente universalista para expressar seu ressentimento em relação à primeira. Por fim, o povo surge na resolução do conflito como punição àqueles que violam suas convenções.

É interessante observar que a condenação do desenlace às vias de fato no Odeon também caminha no sentido de apontar uma falha na hierarquização racial feita tanto pelos que se engajaram na luta física e se valeram de ofensas racistas quanto pelas narrativas veiculadas nos jornais. O "péssimo exemplo" dos protagonistas operou como uma desestabilização dos estereótipos raciais que circulavam no senso comum dos espectadores de cinema e leitores de jornais (em boa parte, sujeitos de classe média), na medida em que o comportamento "incivilizado" daqueles remetia justamente à imagem dos 'outros' racialmente excluídos. O ideal de branqueamento havia sido atacado e seu lugar de autoridade precisava ser restaurado pelos cronistas cariocas. Afinal, como bem frisou Gay sobre os propagandistas da classe média, "a confortável convicção de que a própria raça, nacionalidade ou religião é a vanguarda da humanidade parecia demasiado sedutora e quase irresistível" (2002:132).

Sobre a presença das classes populares no Rio de Janeiro das primeiras décadas do século XX, Sevcenko (1983) e Chalhoub (1996) ponderaram que elas foram sendo segregadas das áreas centrais e nobres da cidade. Enquanto Sevcenko (1983:32-34) destaca o esforço dos ideólogos da Primeira República na higienização do popular através de práticas racistas como a perseguição à capoeira e às religiões de matriz africana, Chalhoub (1996:29-35) amplia este argumento ao ressaltar que uma ideologia da Higiene vinha se afirmando desde a segunda metade do século XIX junto à burocracia estatal, no intuito de perseguir as classes populares e justificar tecnicamente a exclusão destas das áreas de sociabilidade da elite e da classe média em formação.

A percepção de tal exclusão material e simbólica das classes mais baixas operada pela elite e pela classe média também foi explorada por Elias ao analisar a obra de Goethe: 
No Werther, Goethe mostra também com particular clareza as duas frentes entre as quais vive a burguesia. "O que mais me irrita [...] é nossa odiosa situação burguesa. Para ser franco, sei tão bem como qualquer outra pessoa como são necessárias as diferenças de classe, quantas vantagens eu mesmo lhes devo. Apenas não deviam se levantar diretamente como obstáculos em meu caminho'. Coisa alguma caracteriza melhor a consciência de classe média do que essa declaração. As portas debaixo devem permanecer fechadas. As que ficam acima têm que estar abertas. E como todas as classes médias, esta estava aprisionada de uma maneira que lhe era peculiar: não podia pensar em derrubar as paredes que bloqueavam a ascensão por medo de que as que a separavam dos estratos mais baixos pudessem ceder ao ataque" (1994:37).

No caso em questão, a imprensa veiculou a imagem teratológica em torno do povo defendida pelos gestores da Primeira República. O povo é percebido como uma entidade irracional propenso a atos de barbárie e justiçamento primitivo. Os militares protagonistas do confronto definitivamente não esperavam que essas "portas" aludidas por Elias fossem fisicamente ameaçadas pelas classes mais baixas e precisaram se valer da sua posição de classe e de gênero para afirmar suas visões, tal como avaliaremos na próxima sessão.

\section{As artimanhas da ordem: valores e posições de classe e gênero no Rio de Janeiro das primeiras décadas do século XX}

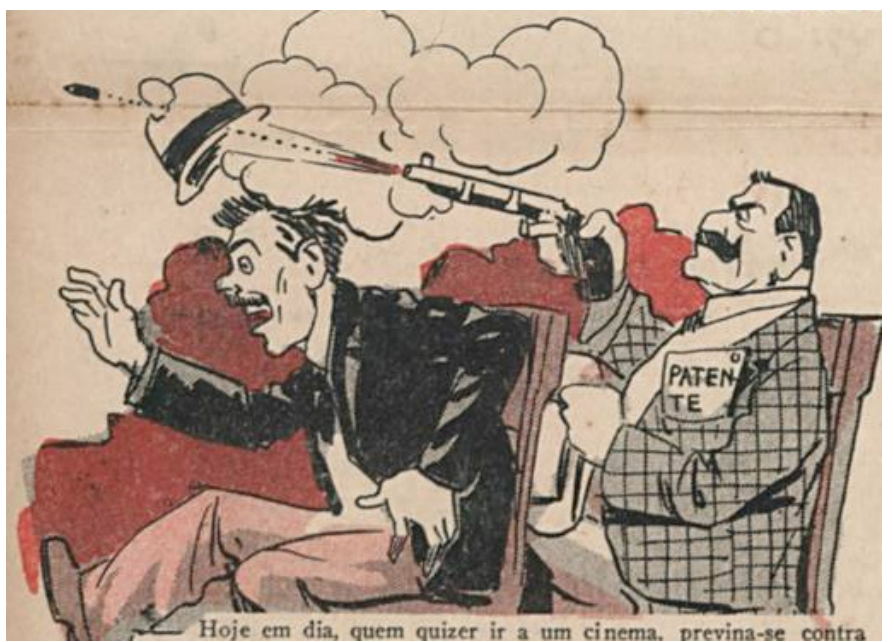

\section{Fonte: Hemeroteca Digital da Biblioteca Nacional}

Neste momento, vale a pena destacar a charge veiculada pela célebre revista satírica $\mathrm{O} \mathrm{Malho}^{17}$ a respeito dos acontecimentos no cinema Odeon. 
Nela, há um homem de meia idade com bigode volumoso e a legenda "patente" no bolso do paletó, com uma arma em riste e disparando-a contra um espectador indefeso.

Esse tom negativo na representação de militares também se fez presente em uma crônica publicada na Gazeta de Notícias: "Seria inacreditavel que tudo isso partisse de dous homens que vestem farda, se já não estivessemos habituados á petulancia injustificavel com que alguns militares se julgam entes superiores, a cuja mercê está sujeita a vida dos civis e a cujas opiniões se devem submetter as proprias leis do paiz"18.

Castro (1995) analisou o perfil dos estudantes de escolas militares do século XIX, salientando sua origem de classe média, e ponderou que "o simples fato de serem letrados já os coloca[va] numa posição muito superior à da massa da população brasileira" (1995:46). Acreditamos que esta observação permanece válida para o início do século XX, visto que a alfabetização ainda não era um fenômeno generalizado.

O autor também observou que a elite foi paulatinamente se mostrando menos interessada em ocupar postos nas forças armadas, uma vez que "a adoção de regras racionais e burocráticas de ascensão na carreira diminuiu a atração que a carreira militar poderia exercer sobre membros da elite, já que reduzia as possibilidades de ascensão através de laços de parentesco ou de apadrinhamento político" (1995:27-28).

Cabe destacar na argumentação de Castro que os exércitos modernos (no qual o brasileiro estaria incluído graças ao seu esforço de modernização) passaram a selecionar seus integrantes desconsiderando sua origem social e, desse modo, a identidade social de seus componentes "deixou de estar referido em um espírito de classe aristocrático e passou a centrar-se na própria instituição. A hierarquia da instituição militar tendeu a desvincular-se da hierarquia social" (1995:19).

Ainda, Castro enfatiza o aspecto meritocrático na ascensão dentro da hierarquia militar (1995:27-32), o que a situa num horizonte de expectativas relacionado à classe média, indo ao encontro de seus anseios, visto que, como já destacou Elias, "a autolegitimação da classe média pela virtude e as realizações tornam-se mais precisas e enfáticas e a polêmica contra as maneiras externas e superficiais encontradas nas cortes fica mais explícita" (1994:29).

O apelo à distinção (Bourdieu 2006) foi feito por ocasião da prisão do coronel Cavalcanti do Rego, detalhe ressaltado em alguns jornais. O cronista da Gazeta de Notícias revelou um aspecto importante: "enquanto isso era feito e antes mesmo da chegada da policia, os coroneis Mendes de Moraes e Cavalcanti do Rego tomavam um automovel e seguiam para a delegacia, não 
permittindo o primeiro desses officiaes que o guarda civil os acompanhasse, alegando a sua qualidade de coronel do Exercito"19. Assim sendo, ser militar mostrou-se uma qualidade que os fazia merecer um tratamento distinto por parte dos agentes da polícia, algo estratégico para o desenlace da trama.

Castro (1995:97-103) percebeu na relação entre civis e militares um drama social que vinha se desenrolando desde meados do século XIX, principalmente a partir da formação de um ethos específico por parte dos militares que os diferenciava da vida dos civis. Desse modo, é possível considerar os militares como um subgrupo dentro da classe média carioca em formação. Com um tom bastante crítico à postura dos militares, a mesma Gazeta de Notícias publicou em outro artigo uma crítica à conduta dos coronéis:

Seguido do clamor publico, é levado a uma delegacia de policia um homem apontado como o desfechador de um tiro, numa sala de espectaculos publicos, com o qual prostara um dos espectadores. Verifica-se que é um coronel da Guarda Nacional, pessoa de posição social e exercendo um cargo de certa evidencia. Ao seu lado, deblatera um coronel do Exercito, protesta contra o depoimento das testemunhas, offerece-lhes desabrida contradita e resolve que não ha nenhum flagrante. O delegado se agacha, de cocoras, a piscar confuso e assustado. Põe-se a prumo devagar e, como quem fosse pisando em ovos, dirige-se ao telephone, e pede conselho e ordens ao seu chefe, que estava áquella hora no theatro, a bater com uma na outra as unhas dos pollegares, pedindo bis a uma copla brejeira. "Ah! Sim. É o coronel Fulano, o preso? E diz o coronel sicrano que não há flagrante? Então, não o lavre ${ }^{20}$ [grifos nossos].

A desvinculação entre a hierarquia social e a militar apontada por Castro (1995:19) assume neste ponto um caráter de imposição da patente militar perante agentes públicos civis e também perante as vítimas e as testemunhas do fato. Em paralelo, o cronista sublinha a subserviência do delegado e a prepotência de Mendes de Moraes como características da relação entre militares e civis. Aqui, o personalismo e o apelo a uma individualidade extrema - um comportamento criticado em membros da elite pela classe média - são reapropriados pelos militares protagonistas no sentido de impor sua leitura dos fatos e tentar escapar à ação da polícia.

Essa dissociação ficou ainda mais evidente na prisão do coronel Cavalcanti do Rego. Os periódicos $A$ Prensa $^{21}$ e $A$ rua ${ }^{22}$ destacaram que o réu foi conduzido ao primeiro regimento de cavalaria do quarto batalhão do Estado-Maior, não sendo conduzido a uma cadeia pública justamente pela sua condição de militar de alta patente ${ }^{23}$.

Neste ponto, é importante fazermos remissão à noção de drama social defendida por Turner (1982): 
Um drama social é iniciado no momento em que o teor pacífico da vida social regular e dirigida por normas é interrompido pela transgressão de uma regra controladora de uma das relações relevantes. Isso conduz rápida ou lentamente a um estado de crise que, se não logo bloqueado, pode dividir a comunidade entre partes e coalisões rivais. Para prevenir isso, medidas compensatórias são tomadas por aqueles que se consideram ou são considerados os representantes mais legítimos ou oficiais da comunidade. Normalmente, a compensação envolve ações ritualizadas, sejam legais (em cortes formais ou informais), sejam religiosas (envolvendo crenças na ação redistributiva de entidades poderosas e supernaturais e frequentemente num ato de sacrifício), sejam militares (por exemplo, conflito, recrutamento ou se engajando em guerras organizadas). [...] Em outras palavras, dramas produzem ou controlam processos reflexivos e geram modelos culturais nos quais a reflexividade pode encontrar um lugar legítimo [grifos do autor, tradução nossa] (Turner 1982:92).

O drama social é revelado aqui como o conflito latente entre sujeitos pertencentes a classes diferentes, com visões de mundo antagônicas que se engajam na luta física - e, depois, judicial - para fazer valerem suas concepções e práticas. Nesse ponto, em muitas narrativas a respeito da contenda no Odeon, a compensação a que Turner se refere traduz-se, em um primeiro momento, no apelo à civilização e à ordem. Posteriormente, a batalha judicial configuraria o outro capítulo das medidas compensatórias.

A cisão entre militares e civis pode ser identificada em vários momentos na cobertura da imprensa sobre o episódio e seus desdobramentos. Em um deles, é noticiado que o acusado de desferir o tiro foi visto passeando pela Avenida Rio Branco e almoçando em um hotel do centro do Rio. Tal fato escandalizou alguns cronistas de jornais cariocas, que protestaram contra a atitude do coronel $^{24}$, revelando uma percepção negativa sobre a impunidade de militares. Desta forma, a fratura entre os dois grupos desempenha papel fundamental no drama social experimentado pelos sujeitos ${ }^{25}$.

A crítica ao papel das forças policiais, especificamente no que diz respeito à questão da ordem, aparece na já mencionada crônica publicada por A Época: "a conducta policial nesse caso do Odeon foi uma vergonha, que deixou na opinião publica a impressão de que é completa a acephalia nesse departamento da administração publica. Uma vergonha e uma inexplicavel pusilanimidade"26.

Acompanhando este tom, outro artigo veiculado pelo Correio da Manhã também lamentou a postura leniente e subserviente da polícia:

O crime praticado há dois dias no cinema Odeon veio por em destaque este facto deveras singular: nos cinemas da nossa capital, não há policiamento. Há 
pouco tempo atras, o chefe de policia, quando organizava a tabela externa do policiamento, nella incluia aquellas casas publicas de diversões. Actualmente, tal inclusão foi suprimida. Por que?

Nos theatros, a pretexto de presidir e policiar os espectaculos, varios supplentes de delegados, quando não autoridades policiaes effectivas, se aboletam na platéa, como assistentes e espectadores curiosos, sem que, porém, se tenham, como toda a gente, premunido dos respectivos bilhetes. [...] De facto, esse crime do Cinema Odeon evidenciou a necessidade prompta de policiamento local. [...] Nada justifica, pois, a exclusão dos cinemas das casas publicas que devem ser policiadas. ${ }^{27}$

É possível estabelecer um paralelo entre o que Sidney Chalhoub chamou de uma "ideologia da Higiene" e uma "ideologia da Ordem", que se destacava na retórica dos cronistas dos periódicos da época. Assim como a primeira, que mascarou visões de classe a partir de demandas pretensamente universais (Chalhoub 1996:5-8), essa ideologia da Ordem também surgiu nesse momento, em consonância com as demandas de uma classe média em formação, que tinha como uma de suas principais características um apelo a instâncias mantenedoras da paz pública, representadas pela polícia e pelas forças armadas, na salvaguarda de seus espaços de sociabilidade.

A crítica à polícia ajudava a canalizar as frustrações dos sujeitos ligados a essa classe média quando não viam plenamente afirmado o projeto (Velho 1994) de ordem tal como pensado pelas elites, concretizado através da reforma urbana da capital federal e encampado justamente por esses mesmos setores médios. No caso analisado, essa crítica alcançou tamanha amplitude na vida pública que foi alvo de cartas de leitores, como a enviada para a redação da Gazeta de Notícias e publicada na edição de 14.2.1916:

Na minha terra, nenhum emprezario, seja de theatro, seja de cinema, montará o seu estabelecimento sem que não preencha todos os fins, dando a maior garantia para o publico e bem estar no recinto. Os cinemas alli são verdadeiros theatros, com todo o conforto, havendo um grande espaço nos vãos das cadeiras e estas bem amplas, de sorte que o espectador não é obrigado a levantar-se, como aqui, para dar passagem a outra pessoa.

Quer nos theatros, quer nos cinemas, o espectador, seja homem, seja mulher, seja creança, é obrigado a tirar o chapéo.

É este o ponto capital a que quero chegar.

Não há duvida que quem vae a um cinema quer ver a fita minuciosamente correr na tela, porém aqui e devido ao desleixo da nossa policia, ninguem tira o chapéo, o que deveria ser obrigatorio, sem excepção de sexo, pois é muito 
desagradavel ter-se na frente um grande chapelão trazendo á parte contrariedade. Eis o motivo por que um rapaz foi victima de uma brutalidade de um soldado, ferindo-o gravemente, quando este estava no seu direito de conservar o chapéo na cabeça e o prejudicado não ter o direito de obrigal-o a descobrir-se. Se tivessemos o regulamento tudo isto seria evitado. ${ }^{28}$

Condensando diversos pontos da celeuma no Odeon, a carta do leitor é encerrada com a sugestão de que a polícia não apenas deveria estar presente nas casas de diversões (algo já veiculado em outras narrativas), como também passasse a regular os códigos de conduta nesses espaços, uma afirmação bastante radical da ideologia da Ordem.

Carvalho $(1990,1998)$ analisou as influências das ideias positivistas do século XIX na construção dos símbolos e dos significados de liberdade e de cidadania na nascente República, enquanto Castro $(1995,2012)$ destacou o papel dessas ideias na formação do Exército brasileiro. Podemos desprender da argumentação dos autores que o apelo à ordem figurava-se como aspecto central da experiência em torno do novo regime. Este aspecto passou a ser veiculado na vida pública não apenas por seus ideólogos, mas também pelos que passaram a se considerar "guardiães da ordem" na conformação do senso comum dos cidadãos cariocas. Neste grupo bastante heterogêneo, certamente podem ser incluídos os cronistas dos periódicos cariocas do período analisado e, de acordo com os sinais encontrados por esta pesquisa, muitos dos leitores desses periódicos, tal como o da carta citada.

Mas esse sentido de ordem encampado por militares e posteriormente por civis não atravessou a Primeira República sem grandes desafios. Em outra oportunidade, Carvalho (1987) frisou que as barreiras legais e institucionais ao exercício da cidadania e a ineficácia do instrumento do voto como afirmação da vontade popular conduziram as classes mais baixas a formas de reivindicação mais violentas - revoltas, motins, rebeliões - que questionavam a ordem tal como pensada pelos ocupantes do poder. Assim, o estigma de "baderneiros" em torno do povo revoltado logo se espalhou pelo senso comum tanto da elite quanto dos setores médios da população, sendo esta imagem de povo fartamente veiculada pela imprensa da época, inclusive convivendo com o estigma antagônico de "bestializados" - apáticos perante as decisões do governo e dos rumos da política - como foi abordado pelo autor.

Embora o sentimento de distinção em relação à população mais pobre seja historicamente um traço constitutivo dos setores médios (Elias 1994; Gay 1989), no confronto analisado, tal sentimento também foi mobilizado contra membros de uma elite aristocrática, já que a vítima alvejada era um 
visconde ${ }^{29}$. Compreender este ressentimento de membros da classe média carioca contra a elite parece-nos elemento fundamental para a identificação das formas de ver o mundo dessa classe em formação e, ainda, para entender como o apelo à ordem também ecoava nesta batalha de visões de mundo entre a elite aristocrática e os representantes dos setores médios.

A apresentação na imprensa da acompanhante de Carvalhaes no cinematógrafo é interessante para clarear este ponto. Qualificada como demi-mondaine em A Época, um eufemismo para designar prostitutas, Line Dunchen dirigiu-se até sua redação para tomar satisfação com o cronista responsável pela matéria e, na confusão, tentou socar o secretário do jornal $^{30}$. Na descrição dos fatos, há uma tentativa de deslegitimar a versão das vítimas por meio da veiculação de um estereótipo misógino contra Line/ Louise: “Esta Louise Deschamps, que outra coisa não póde ser sinão amante do sr. Carvalhaes, á luz dos factos declarados, é mulher capaz de provocar não uma, mas dez tragedias a um só tempo. A prova damol-a ao nosso leitor, com a notícia da aggressão soffrida, hontem, pelo secretario desta folha"31. E encerra a narrativa de modo a enquadrá-la em uma perspectiva que subordina a mulher às relações conjugais: "Não se concebe que uma senhora casada, além de separar do marido para correr o mundo com outro homem, seja capaz de prestar-se a papeis que, como este da aggressão, só combinam e se adaptam aos sentimentos embotados das Imperias relapsas" ${ }^{\prime 2}$.

Devemos ressaltar que, a respeito desses fatos sobre o confronto fisico entre Dunchen e o jornalista, não encontramos a versão de Line em nenhuma fonte e, portanto, dispomos apenas da cobertura com tom abertamente misógino da imprensa. Isso nos remete ao que Ginzburg afirmou a respeito de sua investigação sobre o sabá, mais precisamente que sua atividade como historiador se situou entre a identificação com as vítimas da inquisição e o horizonte intelectual dos inquisidores (2007a). Embora nossas questões de pesquisas coincidam com algumas das levantadas pela imprensa à época (e por isso esses vestígios sejam tão relevantes), precisamos nos distanciar do ponto de vista dos cronistas.

Em artigo veiculado dois dias depois, A Época ataca ainda mais Dunchen. Com o título "Averiguações indispensáveis"33, o cronista cobra da polícia uma investigação a respeito de seu passado:

Neste caso do Odeon, a policia não deve limitar-se, na investigação da verdade, a restabelecer a scena de sangue de que o cinema foi theatro; há outras circunstancias de que ella deve cuidar attentamente e que não são indifferentes para o resultado final do inquerito. Quem é o sr. Carvalhaes? Que veiu elle fazer no Rio? Quem é a rapariga que o acompanha? É uma "demi-mondaine" ou é, antes, uma "toute-mondaine"? 
Não excluamos a hypothese de que seja uma pensionista de Bicêtre ou uma grande dama... dos cafés de Montmartre.

Que o sr. Carvalhaes não é marquez, podemos affirmal-o; supomos que não é visconde nem tem direito a usar qualquer titulo nobiliarchico com que, porventura, a sua vaidade de moço ingenuo queira adonar-se. [...] Nessa obra ajuda-o a carinhosa Louise Luchant; que - com licença do marido, presentemente nas linhas de fogo - anda por este continente 'à faire l'Amérique'".

Podemos inferir que 'prostituta' passa de uma simples insinuação pelo uso do termo demi-mondaine para designar Dunchen e se transforma em categoria de acusação contra ela. A piada machista com as palavras demi-mondaine e toute mondaine e a expressão depreciativa faire l'Amérique usada contra a personagem são fortes indícios de que a honra sexual caminhou pari passu com a afirmação da ordem e de uma visão sobre civilização encampada pelos setores médios.

Ao analisar processos judiciais sobre a honra sexual, Caulfield (2000) apontou que, embora os significados de honra sexual tenham variado e até mesmo confundido juristas, legisladores e forças policiais da Primeira República (e, poderíamos acrescentar, esta indefinição migrou para o senso comum), "proeminentes intelectuais e autoridades públicas do começo do século consideravam a defesa da honra sexual um componente fundamental para a missão civilizadora da recém-proclamada República" (2000:25-26). Haja em vista o debate sobre civilização já sumarizado na parte anterior, não é difícil concluir que o ataque à honra sexual da personagem se inseria na defesa da "civilização tropical" contra o elemento estrangeiro.

Ademais, o uso desta acusação no caso concreto opera no sentido de desqualificá-la como sujeito/testemunha e, assim, construir uma narrativa favorável aos militares que se envolveram na confusão. O tom agressivo da crônica contra Carvalhaes e, sobretudo, seu título nobre antecipam outro elemento presente durante o julgamento do crime: em um primeiro momento, Line Dunchen canalizou o ressentimento de alguns membros da classe média (representada pelos cronistas que a atacaram) que, através do olhar masculino, tentavam devolvê-la ao seu lugar de subordinação, uma vez que "a honra da mulher constitui-se em um conceito sexualmente localizado do qual o homem é o legitimador" (Soihet 2013:389).

O controle da sexualidade das mulheres através da noção de honra sexual estava diretamente relacionado à presença delas no espaço urbano do Rio de Janeiro das primeiras décadas do século XX. No entanto, este controle também era sujeito a falhas e embaraços. Cristiana Schettini, em seu estudo sobre a prostituição no Rio de Janeiro na virada do século XIX para o XX, a partir da análise de um ofício feito por um delegado a respeito 
da frequência a espetáculos (cinematógrafos, teatros), pondera "que a grande dificuldade de reprimir a exibição [de prostitutas] decorria não só dos escândalos provocados por ocasião de uma tentativa frustrada [de repressão], mas também porque os agentes corriam um grande risco de confundir 'senhoras honestas com mulheres da vida airada'" (2006:75). Pelo visto, Dunchen se viu aprisionada nessa complexa rede de significados que atuava na repressão à expressão da sexualidade feminina em termos explícitos, porém deixava margens para atos de subversão.

Hansen (1991:1-20) já havia destacado que o advento do cinema se relaciona diretamente com as transformações da esfera pública, especificamente quanto à presença das mulheres nela. A autora argumenta que os produtores e os exibidores cinematográficos perceberam no público feminino uma importante fonte de capitalização de seus negócios e, ainda, que a partir disso é possível postular um olhar feminino ativo na análise dos filmes do primeiro cinema. Expandindo este argumento e trazendo-o à realidade carioca do início do século XX, podemos dizer que o consumo cinematográfico teve de lidar com as contradições no tratamento às mulheres, fazendo com que o público se inserisse em disputas em torno da honra sexual das frequentadoras de espetáculos de diversão.

Em solidariedade aos colegas de A Época, o jornal O Paiz condenou a agressão de Dunchen:

Mas, é necessária que a Sra. Dunchen saiba que neste paiz há leis, que, se as autoridades a incommodarem com uma intimação para depor, o seu consul nada tem que ver com isso e que, aggressiva na occurrencia do Odeon, não presuma que póde impunemente subir as escadarias das redacções para insultar e aggredir jornalistas, os quaes, de resto, não irão molestal-a no Hotel Moderne, para saber se é ou não por gosto da sua família que ella perambula por estas Americas, detalhe que não nos interessa, senão na medida em que a jovem estrangeira se puzer em destaque neste paiz que deseja ignoral-a sob qualquer dos aspectos com que se apresente" ${ }^{34}$.

Por sua vez, o periódico A rua reproduziu a versão de Dunchen sobre sua relação com Carvalhaes: "Por favor, digam a seu jornal que sou casada em Paris e amiga, somente amiga, do sr. Visconde Carvalhaes" ${ }^{\prime 35}$. Situando as relações de gênero em uma perspectiva histórica (Scott 1986), podemos considerar que, ao responder fisicamente contra os agressores de seu companheiro, Dunchen investiu contra estereótipos que pairavam sobre as mulheres de elite e de classe média ligados à contenção de seu comportamento. Tal investida foi radicalizada na defesa da própria honra sexual às vias de fato, sendo então punida com uma cobertura jornalística que passou 
a contestar sua versão dos fatos e que resvalou no julgamento do crime. Em resumo, misoginia.

Simultaneamente, mulheres eram percebidas como o objeto de tutela da civilização e a falha no autocontrole dos homens colocava em risco sua integridade física e psicológica. Um elemento de destaque nas narrativas sobre o confronto no Odeon foi a presença de mulheres e crianças no cinema na hora do ataque. A Prensa destacou que "as senhoras tiveram crises nervosas"36, enquanto O Imparcial narrou que "o panico que, então, se estabeleceu é indescriptivel. Senhoras e creanças corriam, gritavam, procurando as sahidas do cinema, emquanto as pessoas amparavam o ferido e subjugavam os aggressores" ${ }^{\prime 37}$.

A charge ${ }^{38}$ veiculada por O Malho mostra que a contenda era percebida como domínio eminentemente do masculino, na medida em que só uma mulher (Dunchen) é representada nela e, mais que isso, contraria os relatos de que ela se engajou na luta física ao lado de seu companheiro. Aqui, ela aparece sentada e atônita perante o tiro desferido.

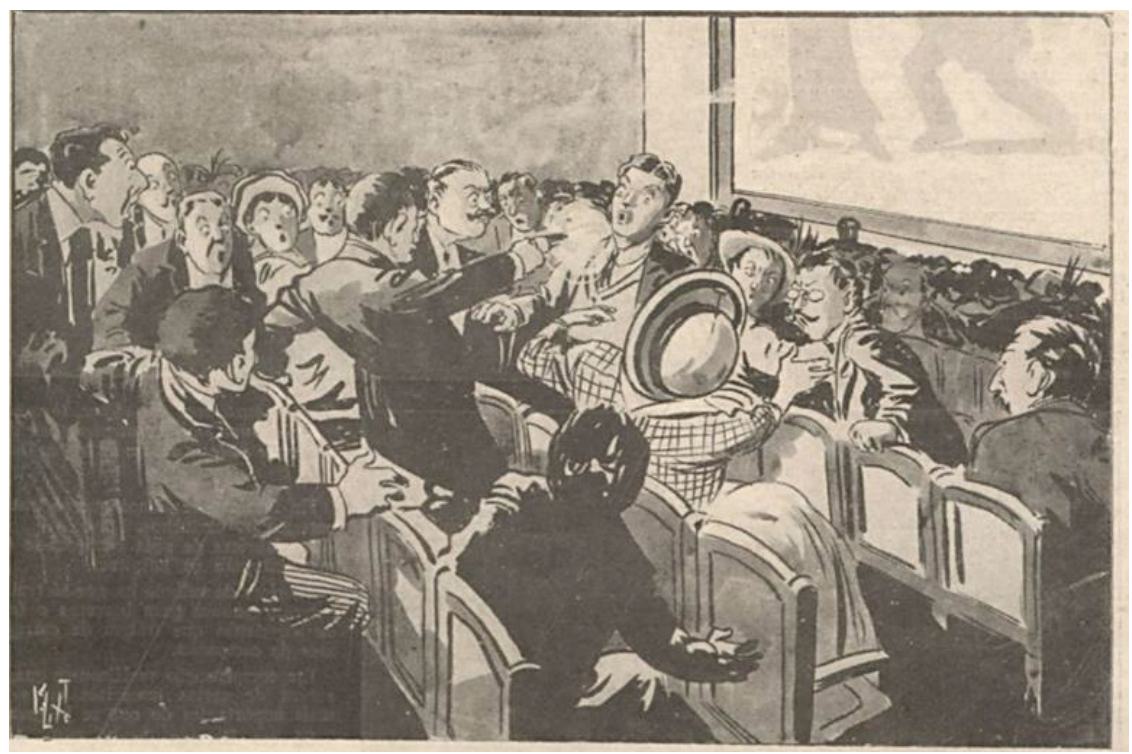

Fonte: Hemeroteca Digital da Biblioteca Nacional

Contra essa representação que tentava enquadrar a mulher como passiva e frágil, os relatos sobre o desenlace sublinharam a persistência de Dunchen em acusar o coronel Cavalcanti do Rego. A Noite observou que ela enfrentou Rego durante o depoimento na delegacia:

Na sala do delegado, á vista do coronel Cavalcanti, disse, com a máxima firmeza:

- Foi este quem deu o tiro. 
Como o coronel Cavalcanti protestasse, dizendo ser falsa tal accusação, porquanto não estava armado, Mme. Louise [Line] cruzou os braços e, olhando-o fixamente, disse-lhe, em francez, porquanto nada falla da nossa lingua:

- O homem que o senhor feriu não morreu ainda e terá, talvez, tempo de fallar. Terá o senhor, diante delle, coragem de negar?

O coronel Cavalcanti pediu então ao delegado que não consentisse que essa senhora continuasse a insultal-o. ${ }^{39}$

Em suma: Dunchen não era casada com Carvalhaes, participou fisicamente na luta contra os que agrediram sua companhia e ainda se contrapôs diretamente à versão apresentada pelos militares. E, como se não bastasse, ainda defendeu fisicamente sua honra contra um cronista que a atacara. Tais atitudes entravam em choque com os estereótipos sobre as mulheres, sobretudo as da elite e da classe média que, de acordo com Soihet, eram enquadradas pela medicina social da época com um conjunto de características que abrangiam "a fragilidade, o recato, o predomínio das faculdades afetivas sobre as intelectuais, a subordinação da sexualidade à vocação maternal. [...] As características atribuídas às mulheres eram suficientes para justificar que se exigisse delas uma atitude de submissão, um comportamento que não maculasse sua honra" (2013:363).

Como o casamento era a principal concretização dessa subordinação das mulheres aos homens, a ausência desta relação foi o mote usado por alguns cronistas para atacar sua legitimidade como testemunha. O uso de demi-mondaine como categoria de acusação à conduta de Dunchen funcionou como a tentativa de reenquadrá-la em outro estereótipo, dessa vez aplicado às "mulheres da rua": uma sexualidade e um comportamento agressivos, que beiravam a histeria, o desrespeito às leis e o desprezo pelos costumes.

O mesmo jornal publicou uma narrativa sobre o seu testemunho durante o julgamento:

Por sua vez Mme. Line exaltou-se bastante. Constantemente narrando o que presenciara, voltava-se para o accusado coronel Cavalcanti e, apontando-o, exclamava, colérica:

- L'assassin!

O Dr. Justo de Moraes frequentemente protestava contra isso, chamando a atenção do juiz, que observava a Madame que sua attitude não podia continuar a ser aquella.

Convidada a substituir a palavra - assassino - ella declarou ser franceza e não encontrar, na sua lingua, outra palavra para designar - "l'assassin"...

Seu depoimento foi forte. Declarou que viu o coronel apontar a arma ao ventre 
de Carvalhaes, desferindo o tiro.

[...] Mme. Line, ao ver a arma, negou terminantemente fosse a mesma que usou o accusado. A de que se serviu o coronel Cavalcanti era maior.

Como o interprete manifestasse difficuldade em comprehender o sentido das perguntas que deveria fazer a Mme., o promotor, desarmando a pistola, deu-a á depoente para que ella mostrasse como que se passou a scena.

Mme., com desenvoltura, pegou da pistola e, levantando-se, apontou-a ao ventre do interprete. Depois fez menção de puxar o gatilho. Apezar de a pistola estar desarmada, o interprete empallideceu.

O tentente Corrêa Lima desagradou a Mme. Dunchen.

Começou a perguntar si ella era casada e com quem, onde estava o marido, etc. Mme. Encheu-se de colera. A sua vida particular não interessava á Justiça, dizia. Não declararia absolutamente nada da sua vida particular.

O juiz fez sentir que a testemunha era obrigada a responder ás perguntas. Ella respondia que sua vida nada interessava à Justiça. E foi essa a resposta constatada. ${ }^{40}$

$\mathrm{O}$ reenquadramento de Dunchen no estereótipo relacionado às "mulheres perigosas" obteve sucesso parcial na hora do julgamento, na medida em que o juiz a constrangeu a revelar sua situação conjugal e a natureza de sua relação com Carvalhaes, e considerou tais fatos relevantes para a credibilidade do testemunho. Ao mesmo tempo, manteve a postura de enfrentamento em relação ao militar acusado pelo crime, inclusive zombando do advogado de defesa em suas respostas.

O combate ao comportamento de uma elite "ilegítima" para o olhar de alguns cronistas dos periódicos cariocas foi se revelando aos poucos, com o desenlace dos fatos, a salvaguarda do próprio lugar de classe (média), seja através dos privilégios pela condição de militar, seja pelo olhar masculino das narrativas sobre o fato que, em geral, deslegitimava o testemunho da personagem feminina envolvida no conflito. Simultaneamente, houve também o descrédito da vítima do tiro. João Vaz de Carvalhaes, que ganhara a solidariedade dos cronistas logo após o fato no Odeon, aos poucos foi sendo retratado como impulsivo, voluntarioso e dotado de um sentimento exclusivista que supostamente lhe permitiria agir de modo diverso das convenções, seja usando um chapéu numa sessão de cinema, seja estando acompanhando de uma mulher com a qual não possui vínculo conjugal.

Inicialmente, não se sabia ao certo quem havia começado a luta física. Com o tempo, a versão que ganhou força foi a de que Carvalhaes teria começado com um soco no nariz do coronel Mendes de Moraes e, 
em seguida, atingido Cavalcanti do Rego com outro soco no rosto. $\mathrm{Na}$ confusão, Mendes de Moraes tentou reagir à agressão, no que foi impedido por Dunchen, que lhe desferiu tapas no rosto e o golpeou com uma sombrinha.

Importante salientar que, em nenhum momento (durante o inquérito policial ou no julgamento), o coronel Cavalcanti do Rego assumiu a autoria do tiro, jogando a culpa para um fictício espectador alterado pela confusão. Tampouco o coronel Mendes de Moraes desmentiu a versão do amigo em qualquer fase da história e mobilizou sua rede de amizades para conseguir espaço nos jornais e veicular sua versão a respeito dos fatos. Assim, a retórica pretensamente universalista em contraposição ao sentimento exclusivista é paulatinamente substituída pela tentativa de se livrar da pena usando o mesmo recurso acionado pela elite, aqui representado pelo apelo a laços de amizade em virtude da posição social.

\section{Considerações finais}

Ao longo desta exposição, verificamos que o fait divers do Odeon condensou um drama social entre militares e civis e, em uma visão mais ampla, entre sujeitos vinculados a uma classe média em ascensão e outros, a uma elite local. A convenção de retirar ou manter o chapéu durante a projeção cinematográfica foi o mote para a deflagração de um conflito de grandes proporções jurídicas e midiáticas, haja vista a vasta cobertura do fato pelos diversos periódicos da época.

Na primeira parte, analisamos como a noção de civilização debatida pelos cronistas revelou-se fundamental para enquadrar as leituras em torno do conflito, tendo esta sido mobilizada não apenas na descrição dos fatos, mas também para estabelecer julgamentos a respeito dos espectadores "brigões". Nesse ponto, o ideal de branqueamento saiu enaltecido tanto pelas ofensas racistas proferidas durante a discussão - que não encontraram nenhum contraponto nas narrativas sobre o fato - quanto também pela reafirmação da autoimagem que os espectadores de cinema faziam de si. Aqui, a "civilização" aparece justamente como a propaganda das qualidades e dos feitos de sujeitos situados racialmente e em termos de classe, embora isso fosse tido como algo "natural" nessa cultura de classe média em formação.

O perigo representado pelo povo na retórica desses setores médios e materializado na invasão do cinema após o tiro por populares foi rapidamente contornado pelo retorno à ordem imposto pelas forças policiais e 
pelo apelo à hierarquia militar feita pelos coronéis logo depois do feito, o que se traduziu no tratamento diferenciado concedido a eles na condução à delegacia e na prisão de Cavalcanti do Rego.

Por sua vez, constatamos na segunda parte o apelo a uma ideologia da ordem, encampada pelos setores médios da população no sentido de preservar sua mobilidade pelo espaço urbano. Tal ideologia traduziu-se na crítica feita pelos artigos nos jornais cariocas aos coronéis envolvidos na contenda e, sobretudo, à atuação das forças policiais na mesma, uma vez que estas foram percebidas como ineficientes, apáticas e subservientes aos militares em detrimento da população civil.

Por fim, averiguamos as estratégias de deslegitimação dos sujeitos relacionados à elite e, por consequência, da sua versão sobre os fatos. Ao apelarem para o estereótipo das "mulheres perigosas" para situar Dunchen como uma demi-mondaine, os cronistas e o juiz desacreditaram a busca da personagem pela sua honra sexual, ferida pelos comentários maldosos. Paralelo a isso, questionaram a validade do título nobiliárquico de Carvalhaes e o foram retratando de forma antipática ao público da época para que este não se identificasse com a vítima. Deste modo, a "civilização tropical" estava a salvo dos perigos impostos por elementos "alienígenas" (mas nem tão alienígenas assim).

Recebido em 29 de junho de 2017

Aprovado em 08 de março de 2018

Pedro Vinicius Asterito Lapera é professor do Programa de Pós-Graduação em Cinema e Audiovisual, Universidade Federal Fluminense, Niterói/RJ, Brasil e pesquisador da Fundação Biblioteca Nacional, Rio de Janeiro/RJ, Brasil. E-mail: <plapera@gmail.com> 


\section{Notas}

1 Fait divers é um jargão do jornalismo usado para se referir a notícias incomuns/ extraordinárias que não podem ser enquadradas dentro de editorias como política ou economia. É importante ressaltar que o termo já era empregado pelos jornalistas do período abordado, inclusive nomeando o caso do cinema Odeon como um fait divers. Cf: "O caso do Odeon". O Paiz, 13.2.1916, p. 2.

2 A maioria das fontes recolhidas para este artigo é apócrifa, o que nos impede de tecer considerações específicas sobre os autores dos artigos e suas redes de sociabilidade. Entretanto, algumas marcas textuais, o perfil dos editores e mesmo o incidente envolvendo Line Dunchen (uma das protagonistas) e os cronistas do jornal A Época nos permitem traçar o perfil destes.

3 Esta personagem foi apresentada com vários nomes pelos diferentes periódicos, ora aparecendo como Line Dunchen, ora como Louise Duchamps (ou mesmo Duchant ou Luchant). Optamos pelo presente nome por este ter sido usado na instrução do processo criminal contra João Cavalcanti do Rego, que será analisado mais adiante.

4 A Noite, 11.2.1916, p. 1

5 A Época, 12.2.1916, p. 1.

6 13.2.1916, p. 2.

7 19.2.1916, p. 20-21.

8 19.2.1916, p. 17.

9 14.2.1916, p. 2.

10 A primeira sala de cinema no Rio de Janeiro - Cinematographo Pariense - foi inaugurada pelo empresário Giacomo Staffa em 1907, menos de 10 anos antes do incidente analisado. Antes dela, a projeção cinematográfica misturava-se a outras atrações, como teatros e cafés-concertos (Araújo 1985).

11 Gazeta de Notícias, 12.2.1916, p. 4.

12 12.2.1916, p. 1.

13 12-13.2.1916, p. 1.

14 Semipúblico na medida em que o pagamento do ingresso é uma condição necessária e excludente para sua fruição.

15 Entre 1 e 2 réis nas áreas centrais da cidade (Rua do Ouvidor, Avenida Rio Branco).

16 Dados extraídos de José Murilo de Carvalho (1987:75). 
17 19.2.1916, p. 20.

18 12.2.1916, p. 1

19 11.2.1916, p. 3.

2013.2 .1916 , p. 1.

21 11.2.1916, p. 1.

2212.2 .1916$, p. 2.

23 Não está claro na análise das fontes se este era um procedimento padrão em se tratando da prisão de militares, mas o tom de espanto da cobertura jornalística nos sugere o contrário.

24 O Imparcial, 17.3.1916, p. 4.

25 A Careta, 19.2.1916, p. 7; O Paiz, 14.4.1916, p. 1.

26 13.2.1916, p. 1.

2713.2 .1916$, p. 1.

2814.2 .1916$, p. 2.

29 Apesar de o episódio se passar durante o regime republicano, adotamos o título de nobreza utilizado pelas fontes ao se referirem a um dos protagonistas.

30 A Época, 12.2.1916, p.1; A Prensa, 12.2.1916, p. 2.

31 A Época, 12.2.1916, p. 1.

32 A Época, 12.2.1916, p. 1.

33 14.2.1916, p. 2.

34 13.2.1916, p. 2.

35 "Faites-moi le plaisir de dire dans á votre jornal que je suis mariée á Paris et amie, soulament amie, de la famille de mr. le Vinconte Carvalhaes". A Rua, 12.2.1916, p. 2.

36 11.2.1916, p.2.

37 11.2.1916, p. 4.

38 19.2.1916, p. 17.

3911.2 .1916 , p. 3.

40 A Noite, 26.3.1916, p. 3. 


\section{Referências bibliográficas}

ARAÚJO, Vicente de Paula. 1985. A bela época do cinema brasileiro. São Paulo: Perspectiva.

BARBOSA, Marialva Carlos. 2007. História cultural da imprensa: Brasil, 1900-2000. Rio de Janeiro: Mauad X.

BERGER, Peter; LUCKMANN, Thomas. 1996. A construção social da realidade. Petrópolis: Vozes.

BOURDIEU, Pierre. 2006. A distinção: crítica social do julgamento. São Paulo: Zouk.

CARVALHO, José Murilo de. 1987. Os bestializados: o Rio de Janeiro e a república que não foi. São Paulo: Cia. das Letras.

. 1990. A formação das almas: o imaginário da república no Brasil. São Paulo: Cia. das Letras.

. 1998. "Entre a liberdade dos antigos e a dos modernos: a república no Brasil". In: Pontos e bordados: escritos de história e política. Belo Horizonte: Ed. UFMG.

CASTRO, Celso. 1995. Os militares e a república: um estudo sobre cultura e ação política. Rio de Janeiro: Jorge Zahar. . 2012. Exército e nação: estudos sobre a história do Exército brasileiro. Rio de Janeiro: FGV.

CAULFIELD, Sueann. 2000. Em defesa da honra: moralidade, modernidade e nação no Rio de Janeiro. Campinas: Editora da Unicamp.

CHAlHOUB, Sidney. 1996. Cidade febril: cortiços e epidemias na corte imperial. São Paulo: Cia. das Letras. . 2012. Trabalho, lar e botequim: o cotidiano dos trabalhadores no Rio de Janeiro da Belle Époque. Campinas: Editora da Unicamp.

COMAROFF, John \& COMAROFF, Jean. 1992. Ethnography and historical imagination. Oxford, Boulder: Westview Press.
CUNHA, Olívia Maria Gomes da. 2002. Intenção e gesto: pessoa, cor, a produção da (in)diferença no Rio de Janeiro (1927-1942). Rio de Janeiro: Arquivo Nacional.

DAVIS, Natalie Zemon. 1990. Fiction in the archives: pardon tales and their tellers in the sixteenth-centure France. Stanford: Stanford University Press.

DOUGLAS, Mary; ISHERWOOD, Baron. 2004. O mundo dos bens: para uma antropologia do consumo. Rio de Janeiro: UFRJ.

ELIAS, Norbert. 1994. O Processo civilizador. Vol. 1: uma história dos costumes. Rio de Janeiro: Jorge Zahar. . 1993. O processo civilizador. Vol. 2: formação do Estado e civilização. Rio de Janeiro: Jorge Zahar. . 1994. A sociedade dos indivíduos. Rio de Janeiro: Jorge Zahar.

GAY, Peter. 2002. O século de Schnitzler: a formação da cultura da classe média (1815-1914). São Paulo: Cia. das Letras. . 1989. A experiência burguesa da Rainha Vitória a Freud: a educação dos sentidos. São Paulo: Cia. das Letras.

GEERTZ, Clifford. 1989. A interpretação das culturas. São Paulo: LTC.

GINZBURG, Carlo. 1987. O queijo e os vermes: o cotidiano e as ideias de um moleiro perseguido pela Inquisição. São Paulo: Cia. das Letras. . 2007. Mitos, emblemas, sinais: morfologia e história. São Paulo: Cia. das Letras. .2007a. História noturna: decifrando o sabá. São Paulo: Cia. das Letras.

GOFFMAN, Erwin. 1988. Estigma: notas sobre a manipulação da identidade deteriorada. São Paulo: LTC.

HANSEN, Miriam. 1991. Babel \& Babylon: spectatorship in American si- 
lent film. Cambridge, Massachussets, London: Harvard University Press.

MOREL, Edmar. 2009. A revolta da chibata. São Paulo: Paz e Terra.

MUSSER, Charles. 1994. The emergence of cinema: the American screen to 1907. Berkeley, Los Angeles, London: University of California Press.

NASCIMENTO, Álvaro Pereira do. 2001. A ressaca da marujada: recrutamento e disciplina na Armada Imperial. Rio de Janeiro: Arquivo Nacional.

NEEDELL, Jeffrey. 1993. Belle Époque tropical: sociedade e cultura de elite no Rio de Janeiro na virada do século. São Paulo: Cia. das Letras.

SCHETTINI, Cristiana. 2006. Que tenhas teu corpo: uma história social da prostituição no Rio de Janeiro das primeiras décadas republicanas. Rio de Janeiro: Arquivo Nacional.

SCHWARCZ, Lilia Moritz. 2005 [1993]. O espetáculo das raças: cientistas, instituições e pensamento racial no Brasil. São Paulo: Cia. das Letras.

SEVCENKO, Nicolau. 1983. Literatura como missão: tensões sociais e criação cultural na Primeira República. São Paulo: Brasiliense.
1984. A Revolta da Vacina: mentes insanas em corpos rebeldes. São Paulo: Brasiliense.

SINGER, Ben. 2001. Melodrama and modernity: early sensational cinema and its contexts. New York: Columbia University Press.

SCOTT, Joan W. 1986. "Gender: a useful category of historical analysis". The American History Review, 91(5):10531075.

SOIHET, Rachel. 2013. "Mulheres pobres e violência no Brasil urbano". In: Mary Del Priore (org.), História das mulheres no Brasil. São Paulo: Contexto, 362-400.

TURNER, Victor. 1982. From ritual to theatre: the human seriousness of play. New York: PAJ Publications.

VELHO, Gilberto. 1994. Projeto e metamorfose: antropologia das sociedades complexas. Rio de Janeiro: Jorge Zahar.

VIANNA, Adriana de Resende Barreto. 1999. O mal que se adivinha: polícia e menoridade no Rio de Janeiro. Rio de Janeiro: Arquivo Nacional. 


\section{CIVILIZAÇÃO TROPICAL EM PERIGO: CINEMA, ELITE E CLASSES MÉDIAS NA BELLE ÉPOQUE CARIOCA}

\begin{abstract}
Resumo
Inserindo-se em uma perspectiva que transita entre a história e a etnografia, este artigo analisa um fait divers ocorrido em fevereiro de 1916 em um cinema do Rio de Janeiro: uma discussão entre espectadores finalizada com um tiro. A questão principal que irá nortear este artigo é: de que modo estes sujeitos pertencentes à classe média e à elite projetaram algumas tensões sociais no consumo cinematográfico por ocasião do fait divers a ser analisado? Como questão secundária, investigamos quais concepções em torno do termo "civilização" foram usadas nas narrativas sobre o caso veiculadas pelos periódicos da época e como estes atuaram nas interpretações do conflito. Nossa hipótese principal é a de que o fato analisado envolve dois polos em termos de classe que estruturam a dinâmica do seu desenlace, sendo uma metonímia de uma série de conflitos entre visões de mundo e de agir dessas classes.
\end{abstract}

Palavras-chave: Cinema, Rio de Janeiro, Belle Époque, classe média.

\section{TROPICAL CIVILIZATION IN DANGER: CINEMA, THE ELITE AND THE MIDDLE CLASSES IN THE CARIOCA BELLE ÉPOQUE}

\begin{abstract}
Situated between ethnography and history, this article analyzes a peculiar event that occurred in a Rio de Janeiro cinema in February of 1916: a discussion between spectators was resolved with a gunshot. The main question that guides this article is: how did these middle class and elite subjects project social tensions concerning the cinema industry onto the peculair event under analysis? As a subsidiary issue, I will investigate the meanings of the term "civilization" used in newspaper narratives about the event, and how these affected and effected interpretations of the conflict. My main hypothesis is that the facts under analysis involve two poles arranged in terms of class that structure the dynamic of its outcome, being a metonym for a series of conflicts between ways of seeing the world and of acting that are characteristic of these classes.
\end{abstract}

Key words: Cinema, Rio de Janeiro, Belle Époque, middle class. 


\title{
CIVILIZACIÓN TROPICAL EN PELIGRO: CINE, ÉLITE Y CLASES \\ MEDIAS EN LA BELLE ÉPOQUE CARIOCA
}

\begin{abstract}
Resumen
Vinculándose a una perspectiva que transita entre la historia y la etnografía, este artículo analiza un fait divers ocurrido en febrero de 1916 en un cine de Río de Janeiro: una discusión entre espectadores que finaliza con un disparo. La cuestión principal que será discutida en este artículo es la siguiente: ¿̇de qué modo estos sujetos pertenecientes a la clase media y a la élite proyectaron algunas tensiones sociales en el consumo cinematográfico por ocasión del fait divers que será analizado? Como cuestión secundaria investigamos cuáles concepciones alrededor del término "civilización" fueron usadas en las narrativas sobre el caso vehiculadas por los periódicos de la época y como estos actuaron en las interpretaciones del conflicto. Nuestra hipótesis principal es que el hecho analizado involucra dos polos en términos de clase que estructuran la dinámica de su desenlace, siendo una metonimia de una serie de conflictos entre visiones de mundo y de actuación de esas clases.
\end{abstract}

Palabras clave: Cine, Río de Janeiro, Belle Époque, Clase media. 
